\title{
Digital Capability Dissected
}

\section{Janne J. Korhonen}

School of Science

Aalto University

Helsinki, Finland

Email: janne.korhonen@aalto.fi

\section{Asif Q. Gill}

School of Software

University of Technology Sydney

Ultimo, NSW 2007, Australia

Email: asif.gill@uts.edu.au

\section{Abstract}

There is a growing interest in digital innovation and transformation among the researchers and practitioners. It has been recognised that being "digital" is not all about digital data and information technologies. The notion of "digital capability" has been increasingly embraced, but definitions of this concept have remained vague and elusive. A salient research question remains: what is digital capability? This question is explored in this paper from theoretical and practical perspectives in the form of a conceptual construct: the Digital Capability Framework (D-CaF). The framework distinguishes six levels and seven dimensions of digital capability. It is intended to provide a foundation to plan and execute digital capability driven innovation and transformation initiatives. Further, it helps identify and prioritise the research areas of high impact for further studies.

Keywords Digital capability, organizational capability, capability, framework, levels 


\section{Introduction}

Helfat and Peteraf (2003) define an organizational capability as "the ability of an organization to perform a coordinated set of tasks, utilizing organizational resources, for the purpose of achieving a particular end result." Assuming that organizational capabilities form a hierarchy (Nelson and Winter, 1982; Collis, 1994; Winter, 2003; Hine et al., 2013), this definition can be applied recursively: each level of capability would call for coordination of lower level capabilities.

Recently, the notion of digital capability has emerged, yet it has remained relatively poorly defined in the literature (Da Silva Freitas et al., 2017). An implicit consensus seems to prevail, however, that digital capability goes beyond mere IT skills (Westerman, Bonnet, and McAfee, 2012), involves digital assets (Sandberg, 2014), and creates value through digital outcomes (Srivasta and Shainesh, 2015). For the purposes of this paper, we define digital capability as an enterprise's capacity to integrate and utilize digital data and information technologies in its products, services, business processes, and organizational systems and practices to create added value to its constituents and beneficiaries.

This capacity would manifest itself along distinct dimensions and be measured in terms of discernible levels of capability, each of which would coordinate and make use of capabilities one level down. In this paper, we identify the level structure and the dimensions of digital capability. An integrative literature review results in our proposed conceptual construct: the Digital Capability Framework (D$\mathrm{CaF}$ ) based on both theory and practice.

\section{Levels of Capability}

It has long been suggested that capabilities form a hierarchy (Nelson and Winter, 1982; Collis, 1994; Winter, 2003; Hine et al., 2013). However, there are few, if any, theoretically well-founded vertical typologies of capabilities. To suggest such a plausible basis, we draw on the Levels of Work (LoW) literature (e.g. Jaques, 1998; Rowbottom and Billis, 1987; Hoebeke, 1994; Macdonald et al., 2006; Olivier, 2010) and on the organizational capability literature. Levels of Work I-VI and the respective Levels of Capability (LoC) are summarized in Table 1 and described below ${ }^{1}$. We suggest that each level of capability calls for a progressively higher level of maturity to coordinate lower level capabilities.

\begin{tabular}{|l|l|l|l|}
\hline LoW & Essence & LoC & Description \\
\hline VI & $\begin{array}{l}\text { Develop inter-organizational } \\
\text { networks to institutionally legitimize } \\
\text { the organization and to ensure its } \\
\text { ecological viability. }\end{array}$ & Adaptive & $\begin{array}{l}\text { The organization's ability to enable quick } \\
\text { responses to and proactive enactment of } \\
\text { disruptive changes in its environment to } \\
\text { sustain its viability and effectiveness. }\end{array}$ \\
\hline V & $\begin{array}{l}\text { Define and articulate the } \\
\text { organization's intent to provide } \\
\text { internal coherence and to determine } \\
\text { its position in the present and future. }\end{array}$ & Strategic & $\begin{array}{l}\text { The organization's ability to use and } \\
\text { dynamically adjust its creative } \\
\text { capabilities vis-à-vis the changing } \\
\text { environment. }\end{array}$ \\
\hline IV & $\begin{array}{l}\text { Interrelate and coordinate a } \\
\text { functioning set of products/services, } \\
\text { structures, systems, internal and } \\
\text { external relationships to maintain } \\
\text { viability in a changing environment. }\end{array}$ & Creative & $\begin{array}{l}\text { Organization-specific, dynamic bundles } \\
\text { of systemic capabilities that underlie the } \\
\text { organization's strategic capability. }\end{array}$ \\
\hline III & $\begin{array}{l}\text { Integrate and manage a work system } \\
\text { of people, technology, and processes } \\
\text { to meet the current and foreseeable } \\
\text { needs of known customers. }\end{array}$ & Systemic & $\begin{array}{l}\text { Dynamic sets of interlinked routines that } \\
\text { constitute responsive and relatively } \\
\text { independent systemic functional wholes, } \\
\text { or work systems. }\end{array}$ \\
\hline II & $\begin{array}{l}\text { Apply knowledge and experience to a } \\
\text { particular situation within prescribed } \\
\text { boundaries and available resources. }\end{array}$ & Routine & $\begin{array}{l}\text { Relatively static routines that allow some } \\
\text { degree of situational latitude. }\end{array}$ \\
\hline I & $\begin{array}{l}\text { Produce a specified output, which is } \\
\text { largely prescribed, tangible and } \\
\text { measurable. }\end{array}$ & Zero & $\begin{array}{l}\text { Concrete and pre-specified elementary, } \\
\text { atomic activities that underlie routine } \\
\text { capabilities. }\end{array}$ \\
\hline
\end{tabular}

Table 1. Levels of capability (cf. Korhonen and Halén, 2017).

${ }^{1}$ We omit the customary Level VII, as it is of lesser practical relevance than the lower ones. 
At the lowest level of work (I), the output of work is clearly prescribed (cf. Rowbottom and Billis, 1987). Work is concrete and geared towards completely specified goals in the most efficient way within defined means, technology and method (Hoebeke, 1994). Commensurate with this level are the zero capabilities at the lowest level of the capability hierarchy: elementary activities in the organization that are so pedestrian that they do not provide even a short-term competitive advantage (Hine et al., 2013).

Next level up (II), the response to each case of work is situational (cf. Rowbottom and Billis, 1987) and depends on judgment. Specific requirements of direct action tasks at Level I are moulded into minimal critical specifications regarding the output, the procedures, the tools and the input (Hoebeke, 1994). Routine capabilities at this level "reflect an ability to perform the basic functional activities" (Collis, 1994). These first-level capabilities (Hine et al., 2013) are static routines that the organization does at any given time given its stock of factors of production (Nelson and Winter, 1982). They are focused on everyday subsistence tasks of the organization using current resources (Hine et al., 2013).

At level III, work aims at systematic provision (Rowbottom and Billis, 1987), addressing the varying needs of today as well as those of tomorrow. Systemic capabilities at this level are dynamic functional capabilities (Hine et al., 2013) that pertain to "repeated process or product innovations, manufacturing flexibility, responsiveness to market trends and short development cycles" (Collis, 1994). They determine the period-by-period augmentation or diminution of the organization's factors of production, which are fixed in short term (Nelson and Winter, 1982). These capabilities are focused on change and use less-patterned routines and more specialized resources (cf. Hine et al., 2013).

Work at level IV entails comprehensive provision (Rowbottom and Billis, 1987) - the means and ends of underlying work systems are adjusted to reshape profitability within the overall business purpose. Creative capabilities at this level operate to extend, modify or create ordinary capabilities (cf. Winter, 2003). These dynamic learning capabilities (Hine et al., 2013) are about organization-specific creative ability - "the more metaphysical strategic insights that enable firms to recognize the intrinsic value of other resources or to develop novel strategies before competitors" (Collis, 1994).

At level V, the scope of work extends to a framework that specifies a general field of need (cf. Rowbottom and Billis, 1987). The focus is on shaping and managing the organization vis-à-vis its environment (Macdonald et al., 2006). Strategic capability at level V would refer to the organization's ability to use its creative capabilities. As such, the notion is comparable to that of organizational capability as defined by Moingeon et al. (1998) and Kangas (1999).

Level VI represents multi-field coverage (Rowbottom and Billis, 1987), where the task is to ensure that the output covers the whole complex of fields of need. Complexity is not so readily contained, but the "great organizational divide" is crossed to a "whole world" view and the perspective is widened from an individual organization to the larger ecosystem. Adaptive capabilities at level VI enable the organization to quickly respond to and effectuate change in its environment to ensure its effectiveness in the shifting context. They enable quick creation of new knowledge (cf. Eisenhardt and Martin, 2000), capacity for continuous innovation (Hamel and Välikangas, 2003; Gill, 2015), and improvised response to rapid, unpredictable, and novel events (cf. Pavlou and Sawy, 2010). As high uncertainty, high risk environments do not allow time to respond effectively, these capabilities often rely on the network (Villar and Miralles, 2014).

\section{Discovery of Dimensions of Digital Capability}

\subsection{Digital Dimensions: Literature Review}

In their Digital Capability Framework, Uhl et al. (2014) identify six core capabilities for organizations to become sustainable and successful: 1) Innovation capability, 2) Transformation capability, 3) IT Excellence, 4) Customer centricity, 5) Effective knowledge worker, and 6) Operational excellence.

Soule et al. (2016) identify three clusters of digital capability: 1) Customer experience: "using technology to address customer expectations or integrate digital channels for customer communication and interaction," 2) Operations efficiency: "optimizing, automating, or streamlining internal processes with more precise data," and 3) Workforce enablement: "using digital tools to facilitate collaboration across boundaries, develop skills, or share knowledge across the organization."

In their study of 150 executives in fifty companies around the world, Westerman, Bonnet, and McAfee (2014) found that "Digital Masters" excel in two critical dimensions: in leveraging technology (digital capabilities) and in leading change (leadership capabilities). The former pertains to how the organization 1) engages with customer, 2) excels in operational processes, and 3) innovates and applies new business models. The latter is about vision, engagement, and technology leadership. 
Tumbas, Berente and vom Brocke (2017) interviewed 35 Chief Digital Officers and identified three domains in which successful CDOs build digital capabilities to drive business value: 1) digital innovation, 2) data analytics, and 3) customer engagement.

Matt, Hess, and Benlian (2015) identify four dimensions of digital transformation strategies: 1) use of technologies (attitudes towards new technologies as well as ability to use these technologies), 2) changes in value creation (the extent to which the use of new technologies has impact on core business activities), 3) structural aspects (such as placement of digital activities in the organizational structure), and 4) financial aspects (both a driver of and a bounding force of the transformation).

Digital business frameworks have also been proposed in industry. IBM Institute for Business Value conducted an early study on digital transformation (Berman and Bell, 2011), identifying the following digital transformation capabilities: 1) Business model innovation, 2) Customer and community collaboration, 3) Cross-channel integration, 4) Insights from analytics, 5) Digitally enabled supply chain, and 6) Networked workforce.

The digital business framework by SAP (2015) has the following five pillars: 1) Customer experience across all channels 2) Supplier collaboration, 3) Core business processes, 4) Workforce engagement, including employees and contractors, 5) Assets and the Internet of Things.

McKinsey's Digital Quotient ${ }^{\circledR}$ (cf. Catlin, Scanlan, and Willmott, 2015) diagnostic features 22 digital capabilities along six dimensions: 1) data-driven digital insights, 2) integrated customer experience, 3) digital marketing, 4) digitally-enabled operations, 5) next-gen technology, and 6) digital enablers (digital strategy, culture, and organization).

Based on the literature, we identified seven dimensions of digital capability as summarised in Error! Reference source not found..

\begin{tabular}{|c|c|c|c|c|c|c|c|c|}
\hline Dimension & 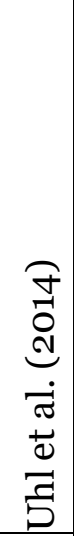 & 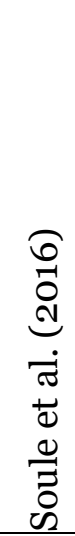 & 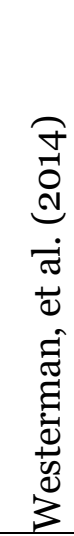 & 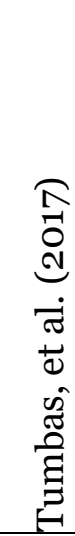 & 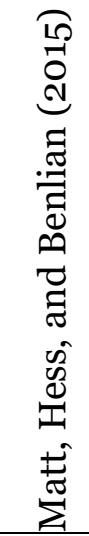 & 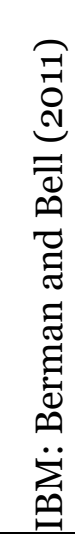 & 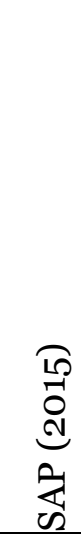 & 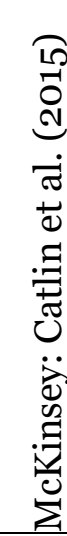 \\
\hline [IT] Information Technology & $\mathrm{x}$ & & & & $\mathrm{x}$ & & & $\mathrm{x}$ \\
\hline [DA] Data and Analytics & & & & $\mathrm{x}$ & & $\mathrm{x}$ & $(\mathrm{x})^{2}$ & $\mathrm{x}$ \\
\hline [CE] Customer Engagement & $\mathrm{x}$ & $\mathrm{x}$ & $\mathrm{x}$ & $\mathrm{x}$ & & $\mathrm{x}$ & $\mathrm{x}$ & $\mathrm{x}^{3}$ \\
\hline [CC] Collaboration and Connectivity & & $\mathrm{X}^{4}$ & & & & $\mathrm{x}$ & $\mathrm{x}$ & \\
\hline [BP] Business Process Excellence & $\mathrm{x}$ & $\mathrm{x}$ & $\mathrm{x}$ & & & $\mathrm{x}$ & $\mathrm{x}$ & $\mathrm{x}$ \\
\hline [KW] Facilitation of Knowledge Work & $\mathrm{x}$ & $\mathrm{x}$ & & & & $(\mathrm{x})^{5}$ & $\mathrm{x}$ & \\
\hline [DB] Digitization of Business & & & $\mathrm{x}$ & $\mathrm{x}^{6}$ & $\mathrm{x}^{7}$ & & & \\
\hline
\end{tabular}

Table 2. Seven dimensions of digital capability derived from the literature.

\footnotetext{
${ }^{2}$ Assets and the Internet of Things.

3 Manifested in the integrated customer experience and digital marketing dimensions.

4 Addressed in Workforce enablement.

5 This aspect is subsumed under Networked workforce, but not its core.

${ }^{6}$ Digital innovation: "Building digital capabilities for intense experimentation, pursuing strategic changes to organizational processes, products, services and business models."

7 Changes in value creation.
} 


\subsection{Digital Dimensions: Practitioners Perspectives}

To avoid any pre-emption and academic bias, we facilitated a discovery workshop, independent of the literature review, with industry experts in Sydney to define the concept of "Digital". It took place on November 30, 2016, and was attended by twelve senior industry leaders and experts. In the workshop, the following themes, underpinning the concept of digital (capability), emerged:

- Value Proposition: Digitising the physical (e.g. less real state) and focusing more on business execution and outcomes (e.g. business agility, save time, ease of operations).

- Digital Interactions: Smooth and seamless multi-channel (e.g. omni-channel) customer experience or interactions or workflow of a networked business.

- Connectivity: Access from anywhere and anytime.

- Digital Business: Customer-centric digital business strategy, models, operating models, capabilities, processes, products and services.

- Analytics and Information Management: Sense-making and getting smart through effective and efficient analytics and information management for timely actionable insights.

- Digital People: Digital talent (e.g. competency), culture and mindset.

- Digital Innovation and Transformation: It is about digital innovation and transformations rather keep doing incorrect things differently.

- Digital Technology: Digital technology such as Agile, Analytics, APIs, Big Data, Blockchain, Cloud, IoT, Mobile, Social and Web enable above mentioned elements.

The findings of the workshop were found to be well in line with the literature study. Both academic and practitioners had similar understanding and perception of the digital dimensions.

It was found that the Information Technology dimension and Digital Technology theme both highlight the central role of (information) technology in the digital capability, albeit they differ in their focus: the former is more about the use and management of IT rather than technology itself. The Data and Analytics dimension seems to be identical to the Analytics and Information theme: how data and information are translated to actionable insights. The Customer Engagement dimension would be best reflected in the Digital Interactions theme, while the Collaboration and Connectivity dimension seems commensurate with the Connectivity theme. The Business Process Excellence and Facilitation of Knowledge Work dimensions that were strongly identified in the literature study did not emerge as clearly as themes in the roundtable discussion. However, they can be seen subsumed by the broad theme of Digital Business. Finally, the Digitizing Business dimension seems to cover aspects from both the Value Proposition and Digital Business themes.

\section{Digital Capability Conceptual Framework}

Based on the levels and dimensions identified and discovered above, we constructed a $6 \times 7$ conceptual Digital Capability Framework (D-CaF), as summarized in Table 3. Each of the dimensions is discussed by each level in the subsections below.

\begin{tabular}{|l|l|l|l|l|l|l|l|}
\hline & IT & DA & CE & CC & BP & KW & DB \\
\hline VI & Adaptive & Prescriptive & $\begin{array}{l}\text { Real-time } \\
\text { context }\end{array}$ & Coadunation & $\begin{array}{l}\text { Intelligent } \\
\text { BPM }\end{array}$ & $\begin{array}{l}\text { Real-Time } \\
\text { Decision- } \\
\text { Making }\end{array}$ & $\begin{array}{l}\text { Digitl } \\
\text { Platform }\end{array}$ \\
\hline V & $\begin{array}{l}\text { Strategic } \\
\text { Value }\end{array}$ & Predictive & Individualized & Collaboration & $\begin{array}{l}\text { Inter- } \\
\text { Enterprise } \\
\text { BPM }\end{array}$ & $\begin{array}{l}\text { Strategic } \\
\text { Work }\end{array}$ & $\begin{array}{l}\text { Digital } \\
\text { Business } \\
\text { Model }\end{array}$ \\
\hline IV & Enablement & Descriptive & Profiling & Coordination & $\begin{array}{l}\text { Collaborative } \\
\text { BPM }\end{array}$ & $\begin{array}{l}\text { Collaboration } \\
\text { Work }\end{array}$ & $\begin{array}{l}\text { Digital } \\
\text { Product Line } \\
\text { / Service } \\
\text { Offering }\end{array}$ \\
\hline III & Service & Reporting & Segmented & Cooperation & $\begin{array}{l}\text { Organizational } \\
\text { BPM }\end{array}$ & Expert Work & $\begin{array}{l}\text { Digital } \\
\text { Product / } \\
\text { Service }\end{array}$ \\
\hline II & Cost & Aggregation & Opt-in & Communication & $\begin{array}{l}\text { Operational } \\
\text { BPM }\end{array}$ & $\begin{array}{l}\text { Integration } \\
\text { Work }\end{array}$ & $\begin{array}{l}\text { Digital } \\
\text { Components }\end{array}$ \\
\hline I & No IT & Query & Solicitation & Coexistence & $\begin{array}{l}\text { Transaction } \\
\text { Processing }\end{array}$ & $\begin{array}{l}\text { Transaction } \\
\text { Work }\end{array}$ & \begin{tabular}{l} 
Non-digital \\
\hline
\end{tabular} \\
\hline
\end{tabular}

Table 3. The Digital Capability Framework (D-CaF). 


\subsection{Information Technology (IT)}

The information technology dimension (IT) pertains to the extent to which the organization is able to leverage information technology and other technologies to support, enable, or drive its work.

The application of IT in organizations has evolved through recognizable eras (Ross and Feeny, 1999; Peppard and Ward, 2004). The respective capability and the institutional level of response seem to have transpired in sync with this evolution.

At the level of zero capabilities (I), IT has no formal presence, but users are purchasing and maintaining systems in a non-integrated ad-hoc manner (Curley, 2007).

At Level II, IT is formally organized to provide utility to the business, but it is viewed purely as a cost centre with key focus on reducing total cost of ownership and increasing return on investment (Curley, 2007). Operational efficiency is improved by automating information-based processes (Ward and Peppard, 2002). Basic IT processes are established and documented (Curley, 2007).

At the systemic (III) level, these routines are interlinked to a systemic functional whole, typically an IT unit that provides business with reliable services (Curley, 2007). The Management Information Systems (Peppard and Ward, 2004) at this level are relatively independent and specific to the work system, whose information requirements they satisfy.

Level IV denotes a shift from the supply-side to the demand-side (sensu Broadbent and Kitzis, 2005). The creative capabilities are about bundling systemic IT and business capabilities in VRIN ${ }^{8}$ ways to create future value. Strategic Information Systems (Ward and Peppard, 2002) are leveraged to improve competitiveness by changing the nature or conduct of business. IT understands the business and proactively proposes solutions to key opportunities and problems (Curley, 2007). The emphasis is on IT effectiveness: maximizing opportunities from IT resources. IT is perceived as investment centre (Curley, 2007) that is focused on IT effectiveness: maximizing opportunities from IT resources.

Along the IT dimension, the strategic capability pertains to the ways in which the creative IT capabilities are built into the very fabric of the organization, enabling it to continuously identify, obtain and sustain IT-based competitive advantage (cf. organizational IS capability, sensu Ward and Peppard, 2002). IT is seen as a value centre (Curley, 2007): business case benefits and value of IT investments can be predicted with high confidence.

Adaptive IT capabilities pertain to how IT can be leveraged to sense and respond as well as to anticipate and pre-empt disruptive changes in the environment (Gill et al., 2014). The organization is "managed by wire" (Haeckel, 1999): IT is used to sense and to make sense of information and to enact pertinent actions more effectively. IT is intrinsically intertwined with business throughout the adaptive cycle of sensing, interpreting, deciding, and acting on data and information.

\subsection{Data and Analytics (DA)}

The Data and Analytics dimension (DA) is about the extent to and way in which the organization gathers, integrates, analyses and acts upon data and information.

At the zero level (I), data is not systematically collected and managed, but resides in task-specific silos,

At the level of routine capabilities (II), data is collected to support procedural decision-making and execution of workflows.

At the systemic (III) level, no advanced analytics are required for foresight. Data is integrated in data marts that typically support operational reporting that informs control decisions, such as assignment of resources to workloads, occur once and are re-used many times, often in a highly-automated system that guides the decision-makers (Saxena and Srinivasan, 2013).

The data challenge at the creative (IV) level calls for the creation of enterprise-wide infrastructure that supports descriptive analytics solutions: what has happened in the past rather than predicting the future. These Analytics 1.0 (Davenport, 2013) solutions typically support decisions to change capacity and set targets with a mix of a few repeatable and process-driven analyses that may be automated and ad-hoc analyses conducted upon request (Saxena and Srinivasan, 2013).

\footnotetext{
8 Valuable, rare, inimitable, and non-substitutable (Barney, 1991).
} 
The strategic (V) data and analytics capabilities pertain to Analytics 2.0 (Davenport, 2013): collecting "Big Data" from the organization's transaction systems as well as from social media platforms, smart sensors, mobile "digital footprints", etc. and providing in-depth predictive analyses that support strategic decisions that have long time-frames and large impact (Saxena and Srinivasan, 2013).

The adaptive (VI) D\&A capabilities are embedded into virtually all operational and decision processes at the front lines of business. To enable quick decisions and actions without human intervention, Analytics 3.0 (Davenport, 2013) is prescriptive, automated and based on real-time stream computing.

\subsection{Customer Engagement (CE)}

The Customer Engagement dimension (CE) is conceptualized as the extent to which customers are known; data on them are collected, integrated, and analysed; marketing messages can be targeted; and feedback be collected and integrated in business processes.

At the zero level (I), customer engagement takes place in encounters upon service interactions, but feedback of the customer on these interactions is not systematically collected nor integrated with relevant processes such as product/service development. There is also no effort to know about the identity of customer, to gather data on customers, or to target market messages to specific audiences.

Routine level (II) CE capabilities include ability to collect feedback from existing customers, to capture basic qualitative customer data (e.g. email address), and to address marketing to an opt-in audience.

At the systemic level (III), basic demographic data on customers is captured e.g. through site registration or social authentication, and integrated across channels to a single customer view. Customer segments can be formed, targeted for marketing, and surveyed for feedback.

Creative level (IV) CE starts with more nuanced customer profiles that can be created based on loyalty programs, data flows from transactions, indicated preferences, social profile information, etc. This data can be used to personalize marketing messages and customer experience. Customer behaviour and preferences can be analysed and forecast to inform new product/service design.

At the strategic level (V), customer understanding is based on demographic, social, transactional, and behavioural data compiled from registration/authentication data, transaction data, and customer engagement tools. The data informs marketing messages and CE at the level of a "segment of one."

Adaptive level (VI) customer engagement is about real-time rendering of individual customer experience, driven by prescriptive analytics and optimization.

\subsection{Collaboration and Connectivity (CC)}

The Collaboration and Connectivity dimension (CC) pertains to how digital data and technologies facilitate technical connectivity and collaborative relationships with external parties.

At the zero level (I), the parties coexist in relative isolation from each other. There are no formal links or roles pertaining to communication or collaboration between the parties.

At level II, connection between collaborating parties is about dialogue and common understanding (Hogue, 1993) to explore interests and to create a base of support (Gajda, 2004). Networking structure is non-hierarchical and based on loose communication links and roles (Hogue, 1993). Decision-making is minimal (Hogue, 1993). There is very little interpersonal conflict (Gajda, 2004).

At level III, fully autonomous collaborating parties share information to support each other's organizational activities (Bailey and Koney, 2000). They match their needs and coordinate with each other to limit duplication of services (Hogue, 1993). A central body of people works as communication hub, within which the roles are somewhat defined. The network links are semi-formal and advisory in nature. (Hogue, 1993). Some collaboration tasks and strategies are identified (Gajda, 2004).

At level IV of Collaboration and Coordination, "otherwise autonomous groups align activities, sponsor particular events, or deliver targeted services in pursuit of compatible goals" (Bailey and Koney, 2000). The collaborating parties share resources to address common issues and merge them to create something new (Hogue, 1993). Links are formalized, roles are defined (Hogue, 1993); communication systems and group decision-making mechanisms are in place (Gajda, 2004). Strategies and tasks are developed and maintained (Gajda, 2004), and the group may leverage or raise money (Hogue, 1993). 
At the strategic level (V), the collaborating parties work collectively through common strategies, and each party relinquishes some degree of autonomy for the joint-purpose (Bailey and Koney, 2000). They develop commitment for a minimum of three years (Hogue, 1993) and merge resources to create or support something new (Gajda, 2004). All members are involved in formal decision-making. Roles and time are defined, and links are formal with written agreements. The group develops new resources and joint budget. (Hogue, 1993).

At the adaptive level (VI), the collaborating parties form a unified "coadunation" relationship, in which "member organizations unite within an integrated structure to the extent that one or all relinquish their autonomy in favour of a surviving organization" (Bailey and Koney, 2000). They build interdependent systems to address issues and opportunities (Hogue, 1993). Strategies and tasks are permanently reorganized, highly formal, and legally complex (Gajda, 2004). Decision-making is based on consensus. Resources and joint budgets are developed. (Hogue, 1993).

\subsection{Business Process Excellence (BP)}

The business process excellence dimension (BP) is about the extent to which business process management and related technologies help automate, integrate, and optimize business processes.

Automation of business processes at the zero level of capability (I) is about performing and supporting day-to-day routine transactions. Transaction Processing Systems (TPS) such as order processing system or machine control are often very critical for the business (Laudon and Laudon, 2017).

At level II, workflow management or business process management systems are used to connect activities in relatively consistent and contained "operational business processes" (cf. Weske, 2007).

At level III, high-level "organizational business processes" (Weske 2007) often cross multiple domains. They can be implemented as either a hierarchy of traditional workflows or as a managed network of participant-specific processes (sensu third wave of BPM as put forward by Smith and Fingar, 2003).

At level IV, the process automation is extended to collaborative end-to-end business processes that involve a number of parties intra- or inter-enterprise. The required business process choreography (Smith and Fingar, 2003) can be achieved through executable BPMN (Business Process Modeling Notation) on sophisticated business process management systems (BPMS) or through formalisms specifically geared to irregular collaborative business processes, such as role activity diagrams (RAD; Ould, 2005) human interaction management systems (HIMS; Harrison-Broninski, 2005).

At the strategic level $(\mathrm{V})$, business process management is integrally embedded in the digital enterprise and is extended throughout the end-to-end value chain to customers, suppliers, distributors and other stakeholders (Rosemann et al., 2006).

The adaptive level (VI) business process management is data-driven and analytics-infused. Real-time business activity monitoring on large volumes of event data is used to continually optimize business processes. Big Data technologies on a Cloud-based architecture are particularly amenable to enable such intelligent BPM (iBPM; sensu Gartner) (Vera-Baquero, Colomo-Palacios, and Molloy, 2016).

\subsection{Knowledge Work Support (KW)}

The knowledge work support dimension (KW) pertains to how and to what extent information technology supports the work of knowledge workers.

Knowledge workers define, analyse, create, maintain, manage, and advise on information resources (Davenport and Prusak, 1997). Davenport (2015) distinguishes four types of knowledge work: transaction work, integration work, expert work, and collaboration work.

Transaction work has a low degree of collaboration and judgment and can typically be scripted. As such, it would pertain to the zero level of capability (I). Computer-based applications can be used to bring the task-specific information to the fingertips of the worker, while measuring the work productivity (Davenport, 2015).

In integration work at the routine level (II), the process is relatively structured and documented for guidance as "standard operating procedures," which the workers have more time and discretion to consult (Davenport, 2015). 
Expert work at the systemic level (III) is highly autonomous and discretionary. Instead of specifying detailed aspects of the workflow, information systems support this type of work best through templates, sample outputs, and high-level guidelines (Davenport, 2015).

Collaboration work seems to be called for at Level IV. It is very unusual for this type of work to be fully mediated and structured by a computer (Davenport, 2015). The knowledge workers are better assisted through "informating" (sensu Zuboff, 1985) rather than automating the processes.

At level V, information systems can support work through hypotheses and tests that help refine the business concept (Cashman and Stroll, 1987). These "flexible organization design systems" must be flexible in the face of constantly changing and complex organizational systems (ibid.).

The adaptive level (VI) adds the requirement of real-time response. This would call for algorithmbased automated decision-making that augments, and partly substitutes, human knowledge work.

\subsection{Digitization of Business (DB)}

The digitization of business dimension (DB) pertains to the extent to which digital data and technologies are embedded in the products, services, and the business model of the enterprise.

At the zero level (I), products are physical and services delivered through non-digital channels. Digital data and technologies are limited to back office support, not interfacing the customer.

At the routine level (II), products have digital components (e.g. a car navigator with updates over the Internet) and services can be accessed through digital channels (e.g. online reservations).

Systemic level (III) digital products (e.g. music, e-books, software) and services (e.g. information services, digital self-service) are fully digital, i.e. they can have a definable market without a physical manifestation or container.

At the creative level (IV), not only some discrete products and services are digital, but entire product lines (e.g. e-books) or service offerings (e.g. digital travel agency) are digital.

At the strategic level (V), digitization is extended to the very business model, i.e. the entire business is purely digital. Examples would include pure-digital e-banks, on-demand video libraries, Cloud infrastructure providers with fully-digital provisioning, etc.

Finally, at the adaptive level (VI), the digital business model is based on digital platforms that provide a substrate for other business to build "planks" on.

\section{Conclusion}

In this paper, we have constructed the Digital Capability Framework (D-CaF), featuring six levels and seven dimensions. The framework is intended to help managers and other practitioners assess and address digital capability requirements to inform digital transformation initiatives. Providing further insights into the types of competencies, systems, structures, and respective investments that will be needed at a given stage of development, $\mathrm{D}-\mathrm{CaF}$ has potential to inform the development of digital capability. The future work includes devising an interview protocol and/or a survey instrument to operationalise and measure digital capability against the vertical scale along different dimensions.

\section{References}

Bailey, D., and Koney, K. 2000. Strategic alliances among health and human services organizations: From affiliations to consolidations. Thousand Oaks: Sage.

Barney, J. 1991. "Firm resources and sustained competitive advantage," Journal of Management (17:1), pp 99-120.

Berman, S.J., and Bell, R. 2011. "Digital transformation: Creating new business models where digital meets physical," IBM Global Business Services Executive report, IBM Institute for Business Value.

Broadbent, M., and Kitzis, E. S. 2005. The New CIO Leader. Boston, MA: Harvard Business School Press. 
Cashman, P.M., and Stroll, D. 1987. "Achieving sustainable management of complexity: A new view of executive support” (3), pp 147-173.

Catlin, T., Scanlan, J., and Willmott, P. 2015. "Raising your Digital Quotient," McKinsey Quarterly, June 2015 .

Collis, D. 1994. "How valuable are organizational capabilities?" Strategic Management Journal (15:S1), pp 143-153.

Curley, M. 2007. “Introducing an IT Capability Maturity Framework.” In: Filipe, J., Cordeiro, J., and Cardoso, J. (Eds.): Enterprise Information Systems: $9^{\text {th }}$ International Conference, ICEIS 2007, Funchal, Madeira, June 2007, Revised Selected Papers, pp 63-80.

Da Silva Freitas, J.C. Jr., Maçada, A.C.G., and Brinkhues, R.A. 2017. "Digital capabilities as key to digital business performance," AMCIS 2017, Paper \#27.

Davenport, T.H., and Prusak, L. 1997. Information Ecology: Mastering the Information and Knowledge Environment. Oxford University Press.

Davenport, T.H. 2013. “Analytics 3.o," Harvard Business Review, (91:12).

Davenport, T.H. 2015. "Process Management for Knowledge Work." In: vom Brocke, J., and Rosemann, M. (Eds.): Handbook on Business Process Management 1, International Handbooks on Information Systems, Second Edition.

Gajda, R. 2004. "Utilizing collaboration theory to evaluate strategic alliances," American Journal of Evaluation (25:1), pp 65-77.

Gill, A.Q. 2015. Adaptive cloud enterprise architecture. World Scientific Publications.

Gill, A.Q., Smith, P., Beydoun, G., and Sugumaran, V. 2014. "Agile enterprise architecture: a case of a cloud technology-enabled government enterprise transformation," PACIS 2014, Chengdu, China.

Haeckel, S. H. 1999. Adaptive Enterprise: Creating and Leading Sense-and-Response Organizations. Boston, MA: Harvard Business School Press.

Hamel, G. ,and Välikangas, L. 2003. ”The quest for resilience," Harvard Business Review, (8:9).

Harrison-Broninski, K. 2005. Human Interactions: The Heart and Soul of Business Process Management. Tampa, FL: Meghan Kiffer Press.

Helfat, C.E. and Peteraf, M.A. 2003. The Dynamic Resource-Based View: Capability Lifecycles, Strategic Management Journal, 24(10), 997-1010.

Hine, D., Parker, R., Pregelj, L., and Verreynne, M.-L. 2013. "Deconstructing and reconstructing the capability hierarchy," Industrial and Corporate Change (23:5), pp 1299-1325.

Hoebeke, L. 1994. Making Work Systems Better: A Practitioner's Reflections. John Wiley \& Sons.

Hogue, T. 1993. Community-based collaboration: Community wellness multiplied. Oregon Center for Community Leadership, Oregon State University.

Jaques, E. 1998. Requisite Organization: A Total System for Effective Managerial Organization and Managerial Leadership for the 21st Century. Rev. $2^{\text {nd }}$ edition. Baltimore, MD: Cason Hall \& Co.

Korhonen, J.J., and Halén, M. 2017. "Enterprise architecture for digital transformation," The 19th IEEE Conference on Business Informatics (CBI 2017), 24-26 July, Thessaloniki, Greece.

Laudon, K.C. and Laudon, J.P. 2017. Management Information Systems: Managing the Digital Firm. 15th ed. Harlow, UK: Pearson Education Limited.

Macdonald, I., Burke, C., and Stewart, K. 2006. Systems Leadership: Creating Positive Organizations, Aldershot, UK: Gower.

Matt, C., Hess, T., and Benlian, A. 2015. "Digital transformation strategies," Business and Information Systems Engineering (57:5), pp 339-343.

Mulligan, P. 2002. "Specification of a capability-based IT classification framework," Information \& Management (39), pp 647-658. 
Nelson, R., and Winter, S. 1982. An Evolutionary Theory of Economic Change, Cambridge, MA: Belknap Press.

Olivier, A. 2013. Organisational Design: What Your University Forgot to Teach You. Xlibris.

Ould, M.A. 2005. Business Process Management: A Rigorous Approach. Meghan Kiffer Press.

Pavlou, P., and El Sawy, O.A. 2010. "The 'third hand': IT-enabled competitive advantage in turbulence through improvisational capabilities," Information Systems Research, (21:3), pp 443-471.

Peppard, J., and Ward, J. 2004. "Beyond strategic information systems: Towards an IS capability," Journal of Strategic Information Systems (13), 167-194.

Rosemann, M., de Bruin, T., and Power, B. (2006). "A Model to Measure Business Process Management Maturity and Improve Performance.” In: Jeston, J., and Nelis, J. (2006): Business Process Management, Chapter 27. Butterworth-Heinemann.

Ross, J.W., and Feeny, D.F. 1999. "The evolving role of the CIO.” In: R. W. Zmud (Ed.): Framing the Domains of IT Management, Projecting the Future... Through the Past, Chapter 19, pp 385402. Cincinnati, OH: Pinnaflex Educational Resources.

Rowbottom, R., and Billis, D. 1987. Organisational Design: The Work-Levels Approach, Aldershot, UK: Gower.

Sandberg, J. 2014. Digital Capability: Investigating Coevolution of IT and Business Strategies. Doctoral Dissertation. Umeå University.

Saxena, R., and Srinivasan, A. 2013. Business Analytics: A Practitioner's Guide. New York: Springer.

SAP. 2015. "Value creation in a digital economy: Adapt or die in a digital world where the consumer is in charge," SAP white paper. SAP.

Smith, H., and Fingar, P. 2003. Business Process Management: The Third Wave. Tampa, FL: Meghan Kiffer Press.

Soule, D.L., Puram, A.D., Westerman, G.F., and Bonnet, D. 2016., "Becoming a digital organization: The journey to digital dexterity," MIT Center for Digital Business Working Paper \#301.

Srivastava, S.C., and Shainesh, G. 2015. "Bridging the Service Divide Through Digitally Enabled Service innovations; Evidence from Indian Health Care Service Providers," MIS Q, (39:1), pp A1A19.

Tumbas, S., Berente, N., and vom Brocke, J. 2017. "Three types of chief digital officers and the reasons organizations adopt the role," MIS Quarterly Executive (16:2), 121-134.

Uhl, A., Born, M., Koschmider, A., and Janasz, T. 2014. "Digital capability framework: A toolset to become a digital enterprise." In Uhl A., and Gollenia, L. A. (Eds.): Digital Enterprise Transformation: A Business-Driven Approach to Leveraging Innovative IT. Routledge.

Vera-Baquero, A., Colomo-Palacios, R., and Molloy, O. 2016. "Real-time business activity monitoring and analysis of process performance on big-data domains," Telematics and Informatics (33:3), pp 793-807.

Villar, E.B., and Miralles, F. 2014. "Beyond resources and dynamic capabilities during disaster response: Response organizations in turbulent and networked environment: The case of a disaster response organization's simulated response to chemical spill disaster," 2014 International Conference on Humanoid, Nanotechnology, Information Technology, Communication and Control, Environment and Management (HNICEM), IEEE.

Ward, J., and Peppard, J. 2002. Strategic Planning for Information Systems. Wiley.

Weske, M. (2007). Business Process Management: Concepts, Languages, Architectures. Springer.

Westerman, G., Bonnet, D., McAfee, A. 2014. Leading Digital: Turning Technology into Business Transformation. Boston, MA: Harvard Business Review Press.

Winter, S. 2003. “Understanding dynamic capabilities," Strategic Management Journal (24:10), pp 991-995.

Zuboff, S. 1985. Automate/informate: the two faces of intelligent technology, Organizational Dynamics (14:2), pp 5-18. 


\section{Acknowledgements}

The author Janne J. Korhonen wants to thank The Foundation for Economic Education in Finland for a travel grant that partly enabled writing this contribution.

\section{Copyright}

Copyright: (C) 2018 authors. This is an open-access article distributed under the terms of the Creative Commons Attribution-NonCommercial 3.0 Australia License, which permits non-commercial use, distribution, and reproduction in any medium, provided the original author and ACIS are credited. 